\title{
A prospective cohort study of digital cushion and corium thickness. Part 2: Does thinning of the digital cushion and corium lead to lameness and claw horn disruption lesions?
}

\author{
R. F. Newsome, ${ }^{* 1}$ M. J. Green, ${ }^{*}$ N. J. Bell, $†$ N. J. Bollard, ${ }^{*}$ C. S. Mason,ł H. R. Whay,§ and J. N. Huxley* \\ *University of Nottingham, School of Veterinary Medicine and Science, Sutton Bonington Campus, Sutton Bonington, Leicestershire, LE12 5RD, \\ United Kingdom \\ †Royal Veterinary College, Hawkshead Lane, North Mymms, Hertfordshire, AL9 7TA, United Kingdom \\ ¥Scotland's Rural College (SRUC), Kings Buildings, West Mains Road, Edinburgh, EH9 3JG, United Kingdom \\ $\S S c h o o l$ of Veterinary Sciences, University of Bristol, Langford House, Langford, BS40 5DU, United Kingdom
}

\begin{abstract}
The aim of this study was to determine whether a decrease in thickness of the sole soft tissues (SST) beneath the flexor tuberosity of the distal phalanx (i.e., the digital cushion and corium) predisposed a claw to develop claw horn disruption lesions (CHDL) or a leg to lameness. Data were analyzed from a longitudinal study of 179 cows, which had been examined at 5 assessment points $-8,+1,+9,+17$, and +29 wk relative to their first, second, third, or fourth calving. At each assessment point, SST were measured using ultrasonography. Additional assessment point data included sole lesions and back fat thickness (BFT), and cows had been locomotion scored every 2 wk from calving. One hundred fifty-eight cows completed the study. Separate logistic regression survival analyses were constructed to assess the outcomes, either lameness on a leg or CHDL on a claw; combinations of lameness and lesions were tested as outcomes. Cow level variables tested included farm and lactation number. Variables were tested describing previous SST thickness, minimum previous SST thickness, BFT, and change in either variable between prior assessment points. Prior lesions/lameness strongly predicted repeat cases and the final models had the outcome first lesion or lameness on a claw or leg. In the reported lameness models, lameness was defined as a leg being recorded as lame twice within 3 consecutive scores, and in the reported lesion models, lesion was defined as the first presence of either a sole ulcer or a severe sole hemorrhage on a claw. Thin SST increased the likelihood of lesion occurrence; thin SST on the lateral claw predicted subsequent lameness on a leg. Thin BFT and thinning of BFT between previous
\end{abstract}

Received September 18, 2016

Accepted February 19, 2017.

${ }^{1}$ Corresponding author: reuben.newsome@gmail.com assessment points increased the likelihood of future lesion occurrence. Thin SST and thinning of BFT had additional effects on the likelihood of lesion occurrence, suggesting that BFT and sole SST had independent effects on lesion occurrence. However, change in SST thickness between assessment points did not influence the likelihood of future lesions or lameness. This suggests that thin SST were not simply a result of depletion of body fat and challenges the theory that thinning of the digital cushion with body fat mobilization leads to CHDL. Other possible mechanisms by which SST become thin are discussed and could include changes in integrity of the suspensory apparatus with physiological events.

Key words: dairy cow, lameness, claw horn disruption lesion, digital cushion

\section{INTRODUCTION}

Lameness from claw horn disruption lesions (CHDL) continues to be a profound economic and a severe welfare issue in developed dairy systems (Barker et al., 2007; Cha et al., 2010; Foditsch et al., 2016). The disease process behind CHDL is not fully understood, but lesions are thought to occur in the claw capsule as a result of excessive forces on the germinal epithelium that produces the horn, causing contusions, hemorrhage, interruption to cell proliferation, epidermal differentiation and cornification, and in severe cases, complete failure of horn production, which manifests as ulceration (van Amstel and Shearer, 2006; Nuss, 2014). The forces on the germinal epithelium are exerted by the distal phalanx during foot strike and standing; therefore, the suspensory and supportive structures that determine the position of the distal phalanx within the hoof capsule appear to be pertinent in claw horn disruption.

A syndrome often termed subclinical laminitis has long been suggested to weaken the suspensory appa- 
ratus, occurring through endotoxin release secondary to SARA and a systemic inflammatory response, causing the distal phalanx to sit lower in the hoof capsule, allowing greater forces to be transferred through the sole of the foot, and predisposing CHDL. This causality has yet to be proven in relation to CHDL, and laxity of the suspensory apparatus appears to largely be superseded by mechanisms other than this classical laminitis theory (Danscher et al., 2010). For example, physiological changes around calving appear to influence the integrity of the suspensory apparatus and predispose CHDL, likely being mediated through matrix metalloproteinase activation with hormonal changes around calving (Tarlton et al., 2002; Knott et al., 2007; Newsome et al., 2017). This suggests that integrity of the suspensory apparatus in the development of CHDL appears to be important, yet not fully understood.

In addition to the suspensory apparatus, the supportive apparatus also determines the position of the distal phalanx within the hoof capsule. A key supportive structure is the digital cushion, which is a connective tissue capsule containing discrete depots of fat that sit beneath the distal phalanx (Räber et al., 2004). Several studies have measured the combined thickness of the digital cushion and corium, collectively to be termed sole soft tissues. (Importantly, previous studies assessing the digital cushion in live cows have all measured the combined thickness of the 2 tissues, rather than measuring the digital cushion alone.) Such works have demonstrated that thin sole soft tissues increased the likelihood of a cow developing CHDL, either during the lactation (Bicalho et al., 2009; Toholj et al., 2014), or during the subsequent lactation if measured at the point of the previous drying off (Machado et al., 2011). Additionally, Newsome et al. (2017) found that cows that developed sole ulcer or severe sole hemorrhage had thinner sole soft tissues, except when a sole ulcer was present on a claw, when the sole soft tissues were thicker.

Loss of body condition has been shown to precede the onset of lameness, measured by both visual detection (Lim et al., 2015; Randall et al., 2015) and lesion treatment (Green et al., 2014). A key hypothesis surrounding this association is that fat is lost from the digital cushion during negative energy balance, causing the digital cushion to become thinner, leading to a decrease in its force-dissipating capacity (Bicalho et al., 2009; Newsome et al., 2017). Although minimum thickness at a single assessment point (AP) has been shown to predispose lameness or lesion incidence (Bicalho et al., 2009; Machado et al., 2011; Toholj et al., 2014), no work has demonstrated that thinning of the sole soft tissues predisposes to lesions or lameness. The aims of this work were to determine whether change in sole soft tissue thickness, minimum previous sole soft tissue thickness, or sole soft tissue thickness at the previous AP predisposed CHDL or lameness in free-stall housed dairy cows.

\section{MATERIALS AND METHODS}

\section{Study Design}

A prospective cohort study, which was described in full by Newsome et al. (2017), repeatedly measured the combined thickness of the digital cushion and corium (termed sole soft tissue thickness) at 3 sites on the hind claws of dairy cows. The principal components of the study design are described here, and the null hypothesis for this analysis stated that change in sole soft tissue thickness did not increase the likelihood of either impaired locomotion or CHDL incidents.

One hundred seventy-nine Holsteins cows in 2 highproducing automatic milking system farms were studied during first, second, third, or fourth lactation, from before calving. Cows were housed year-round and farm systems are described by Newsome et al. (2017). Measurements were taken from cows at $5 \mathrm{AP}$, which were between approximately $8 \mathrm{wk}$ before and $35 \mathrm{wk}$ after calving $(\mathrm{AP}-8, \mathrm{AP}+1, \mathrm{AP}+9, \mathrm{AP}+17$, and $\mathrm{AP}+29$, indicating the number of weeks relative to calving). At each of the $5 \mathrm{AP}$, cow data were collected as follows: (1) BCS on a 1 to 5 scale with quarter-point intervals (Wildman et al., 1982; Edmonson et al., 1989); (2) an ultrasonographic measurement of back fat thickness; (3) hind feet were lifted in turn, trimmed if overgrown, the sole surface was prepared for visualization of lesions, and a digital photograph of the base of the foot was taken and stored for lesion analysis; and (4) ultrasonographic measurements of sole soft tissue thickness were taken at 3 sites beneath the distal phalanx. The measurements were taken from the inner margin of the sole horn to the border of the distal phalanx, through and perpendicular to the sole, beneath (1) the apex of the distal phalanx, (2) the highest point of the arch on the base of the distal phalanx, and (3) beneath the flexor tuberosity (Newsome et al., 2017). In addition to the collection of data at AP, all cows were locomotion scored every 2 wk.

\section{Locomotion Assessment}

Locomotion scoring was performed every 2 wk between calving and 35 wk postcalving, by one trained, blinded observer on each farm. The Agriculture and Horticulture Development Board Dairy 0 to 3 mobility 
scoring system was used, which is the UK industry standard (Thomas et al., 2015). Cows were observed from behind during unrestricted walking in the passageways where cows were housed. Briefly, $0=$ sound, with even weight-bearing on all limbs, $1=$ imperfect locomotion but not identifiably lame, 2 =identifiably lame on a leg (i.e., decreased weight bearing was identifiable), and 3 $=$ severely lame. Scores 2 and 3 were divided into $2 \mathrm{~A}$, $2 \mathrm{~B}, 3 \mathrm{~A}$, and $3 \mathrm{~B}$ to enable greater discretion between different severities of lameness, and to allow for aggregation back to fewer categories if required. Locomotion scores were leg-specific (i.e., a cow could be given a lame score on each leg; for example, $2 \mathrm{~A}$ left hind and $2 \mathrm{~B}$ right hind at the same locomotion scoring).

The 2 observers had been trained using this locomotion scoring system and had used the system during previous research studies (Thomas et al., 2015, 2016). Inter-observer tests were performed as follows: 176 cows were locomotion scored by both observers during the same passage of walking. Inter-observer repeatability tests revealed Cohen's kappa values of 0.66 (95\% CI: 0.48 to 0.83 ) for determining whether a cow had a score of $\leq 2 \mathrm{~A}$ or $\geq 2 \mathrm{~B}$ (i.e., $66 \%$ of classifications were consistent between observers, in addition to expected agreement by chance alone), or 0.57 (CI: 0.40 to 0.73 ) for determining whether a cow had a score of $\leq 2 \mathrm{~A}$ on either leg, $\geq 2 \mathrm{~B}$ on the right hind leg, or $\geq 2 \mathrm{~B}$ on the left hind leg. Inter-observer repeatability tests were poorer when discerning between a $\leq 1$ (nonlame) and $\geq 2 \mathrm{~A}$ (lame) score; kappa was 0.46 (CI: 0.35 to 0.58 ).

\section{Claw Horn Disruption Lesion Assessment}

A lesion scoring system was designed based on descriptors in the peer-reviewed literature; images of prepared feet (i.e., either after trimming if it had been required, or after the sole surface had been skimmed with a hoof knife) were scored as follows. Sole, heel, and toe ulcers were recorded; ulcer was defined as full depth penetration of the horn (Leach et al., 1997). Sole hemorrhage, white line hemorrhage, and white line separation were each assigned 1 of 3 severities: mild, moderate, or severe; the most severe lesion of each type present on each claw was recorded. Hemorrhage category definitions were mild: slight hemorrhagic discoloration; moderate: darker discoloration up to dark pink; or severe: profound, dark pink, red, or purple discoloration (Leach et al., 1997; Sogstad et al., 2007). White line separation category definitions were mild: marks along the white line; moderate: deep, affected fissures; or severe: very deep, profound fissures with either involvement of the corium, purulent exudate, necrosis, granulation tissue, or separation of the wall
(Sogstad et al., 2007). Region of the foot was identified as recommended by the standard foot map (Greenough and Vermunt, 1991), and digital dermatitis was classified according to the M-scale (Döpfer et al., 1997) including the M4.1 category (Berry et al., 2012).

Images taken of each claw at each AP (Newsome et al., 2017) were analyzed for lesions, according to the above scoring system, in the open-source platform Fiji (Schindelin et al., 2012) for the image analysis software ImageJ (Schneider et al., 2012). A single independent observer was trained to use the lesion scoring system, after which they were tested for consistency by scoring a subset of the data set (25 images) on 2 consecutive days. Intra-observer agreement tests showed $\kappa=0.96$ (CI: 0.90 to 1) for lesion identification, 0.83 (CI: 0.69 to 0.98 ) for identification of lesion and severity combined, and 0.93 (CI: 0.83 to 1 ) for identification of region, and was considered to be very good. The full data set (consisting of 1,569 foot-AP images) was then randomly ordered and scored, and images from every 50th AP throughout the study were included twice at random locations. The observer was blind to which images had been scored twice, and $\kappa$ values between the 2 repeat scores were 0.76 (CI: 0.63 to 0.87 ) for lesion identification, 0.74 (CI: 0.66 to 0.83 ) for lesion and severity, and 0.66 (CI: 0.57 to 0.75 ) for region.

\section{Statistical Analysis}

Mixed effect logistic regression models were constructed to explore relationships between explanatory variables and either lesion (claw level, at an AP) or hind limb lameness (leg-level, at a locomotion score) outcomes. Fore limb lameness events were not considered in the analysis. All models were constructed in MLwiN 2.26 (Rasbash et al., 2009) using iterative generalized least squares algorithms and a forward stepwise procedure. These models equated to Cox proportional hazards models with random effects, as shown by Yang and Goldstein (2003), and can be termed frailty models, time-to-event analyses, or survival analyses (Cox and Oakes, 1984; Goldstein, 2003).

Survival Analyses to First Lesion Incident (Model 1). Models had the outcome "first lesion occurrence on a claw at an AP (yes or no)" and were constructed to test a variety of claw horn lesion outcomes, including either the presence of a specific CHDL (i.e., sole ulcer, severe sole hemorrhage, severe white line hemorrhage, or severe white line separation), or a combination of lesions. The model had 3 levels and took the following format:

$$
Y_{i j k} \sim \text { Bernoulli (probability }=\pi_{i j k} \text { ), }
$$




$$
\begin{gathered}
\operatorname{logit}\left(\pi_{1 i j k} / \pi_{0 i j k}\right)=\alpha+\beta 1 X_{j}+\boldsymbol{\beta} 2 X_{i j} \\
+\beta 3 X_{i j k}+v_{k}+u_{j k} \\
v_{k} \sim N\left(0, \sigma_{v}^{2}\right) \\
u_{j k} \sim N\left(0, \sigma_{u}^{2}\right)
\end{gathered}
$$

where $Y_{i j k}$ was the first incident of a lesion on a claw during the study period, at the ith claw-AP of the $j$ th claw of the $k$ th cow; $\pi_{1 i j k}$ was the probability of a first lesion being present at a claw-AP; $\alpha$ was the intercept; $\boldsymbol{\beta} 1, \boldsymbol{\beta 2}$, and $\boldsymbol{\beta 3}$ represent vectors of coefficients; $X_{j}, X_{i j}$, and $X_{i j k}$ represent fixed effects variables at the cow, claw, and claw-AP levels, respectively; and $v_{k}$ and $u_{j k}$ were random effects at the cow and claw levels (inclusion of the random effects allowed claws within cow, or repeated assessments of a single claw, to not be treated as independent, respectively). Cow level data were tested as in Newsome et al. (2017). A claw-level categorical variable distinguished between the lateral and medial claw. Days in milk was tested as the time variable up to the fourth power. Descriptors of back fat thickness and sole soft tissue thickness at sites 1, 2, and 3 from previous AP, including at specific previous AP, were lagged to explore whether prior thickness of any structure, change in thickness, minimum previous thickness, or thickness at any previous AP influenced the odds of a lesion incident. Biologically plausible interactions were tested. Descriptors of body condition score were not tested in the model because they were found to be unyielding by Newsome et al. (2017). Several similar models with different outcomes were tested to explore associations in different cohorts of animals [e.g., lactation 1 animals only because previous works have demonstrated differences in the content of the digital cushion (Räber et al., 2006) or the relationship between fat mobilization and lameness (Randall et al., 2015) in heifers] or where outcomes were taken at different AP.

Initially, once the outcome had occurred on a claw, the claw remained in the model and the previous occurrence of a lesion was indicated using a dummy variable. However, previous occurrence of a lesion strongly predicted the occurrence of a lesion and the influence of other fixed effects became nonsignificant. Therefore, the outcome of the final models was the first incident of a lesion on a claw during the lactation, and subsequent claw records were excluded from the analyses.

Survival Analyses to First Lameness Events (Model 2). The model tested a first incident of lameness on a hind leg during the study period, measured by a locomotion score every 2 wk. Models were constructed to test a variety of lameness outcomes, where a lame event on a leg could be defined as a score $\geq 2 \mathrm{~A}$ at a single locomotion score, or as either $\geq 2 \mathrm{~A}$ or $\geq 2 \mathrm{~B}$ at multiple consecutive locomotion scores. As with the lesion models, a lameness event strongly predicted future lameness; therefore, in the final models legs remained in the model until the first lameness event. Model 2 was tested with 3 levels and had the same structure as model 1, except where model terms represented different parameters, as follows: the outcome $\mathrm{Y}$ was either a lame or nonlame state at the $i$ th locomotion score of the $j$ th leg of the $k$ th cow, $\pi_{1 i j k}$ was the probability of that leg being lame at that locomotion score, and $v_{k}$ and $u_{j k}$ were random effects at the cow and the leg levels. Cow-level explanatory variables were tested, as well as lagged back fat thickness and sole soft tissue thickness as for model 1. Sole soft tissue thicknesses on each claw and average sole soft tissue thickness across both claws on a leg were tested. The model was also constructed to assess time-to-event relationships between measures of sole soft tissue thickness and lameness.

The Wald test was applied to determine whether fixed effects were to be retained in a model (i.e., a variable was significant when the coefficient was $\geq 1.96$ $\times \mathrm{SE} ; P \leq 0.05)$. Goodness of fit for survival models was assessed using posterior predictions (Hosmer and Lemeshow, 1989), with and without random effects. Residuals at higher levels were inspected to assess normality. Random effects were retained in the model if they improved model fit.

\section{RESULTS}

\section{Overview of the Data Set}

One hundred fifty-eight cows completed the entire study, having been assessed at all 5 AP and follow-up locomotion scores. Descriptive data on sole soft tissue thickness, back fat thickness, and lesion incidence were presented by Newsome et al. (2017); in brief, back fat thickness at each AP (AP-8 to AP+29) was $18.9 \mathrm{~mm}$ (SD: $5.7 \mathrm{~mm}$ ), 16.6 (5.9), 11.1 (5.0), 10.9 (5.3), and 13.3 (5.8), and sole soft tissue thickness at site 3 at each AP was $5.22 \mathrm{~mm}$ (SD: $0.91 \mathrm{~mm}), 4.68$ (0.87), 4.89 (0.90), $5.02(0.96)$, and 5.20 (0.97).

Lesion incidence data are displayed in Table 1, demonstrating first and repeat lesion cases for parity 1 and parity $>1$ animals. Forty-seven sole ulcers were recorded throughout the study period, on 5 parity 1 and 33 parity $>1$ animals (some animals had $>1$ instance of the lesion recorded during the study period, including repeat cases or cases on a different claw, as 
detailed in Table 1). One hundred fifty-one cases of sole hemorrhage were recorded, affecting 34 parity 1 and 66 parity $>1$ animals. Seven cases of white line hemorrhage were observed in heifers and 11 in cows, whereas no white line separation cases were observed in heifers but 8 were observed in cows.

A total of 5,142 leg-locomotion scores of the hind legs were collected, and Figure 1 demonstrates the incidence of first leg lameness during the study period for locomotion score categories $2 \mathrm{~A}, 2 \mathrm{~B}$, and $3 \mathrm{~A}$. Incidence of first $2 \mathrm{~A}$ scores was highest during the first $30 \mathrm{~d}$ of lactation. Incidence of both first $2 \mathrm{~B}$ and first $3 \mathrm{~A}$ scores peaked at 120 to 150 DIM.

\section{Survival Analyses of First Lesion Incidents}

Overview of Final Lesion Models. The outcome for the lesion models was the first presence of either a sole ulcer or a severe sole hemorrhage on a claw (yes or no). Reported models were fixed-effects survival models and model fit was good; model fit deteriorated with the inclusion of random effects; therefore, random effects were omitted. Three final lesion models are presented (Table 2) exploring (1a) lesion incidents after calving, (1b) lesion incidents following change in sole soft tissue or back fat thickness (i.e., after 2 previous AP), or (1c) lesion incidents in heifers only, and are described below. Broadly, the presented models demonstrated that lesions (sole ulcer or severe sole hemorrhage) were more likely to occur on the lateral claw compared with the medial and on the claws of lactation 3 and 4 animals (models $1 \mathrm{a}$ and $1 \mathrm{~b}$ ). Thin sole soft tissue thickness at site 3 increased the likelihood of subsequent lesion incident on a claw. Thin sole soft tissues did not significantly increase the odds of any white line lesions, or sole hemorrhage lesions of mild or moderate severity. No difference was observed in lesion incidence between farms, except in parity 1 animals, where incidence was higher on farm 2 (model 1c).

Model 1a. The outcome for model 1a was first lesion incident (either a sole ulcer or severe sole hemorrhage) on a claw at any AP after calving; 2,255 claw assessments of 676 claws of 176 cows met the criteria for the model, of which first lesions were observed on 113 claws postcalving, of which 97 occurred on lateral claws. The minimum previously recorded sole soft tissue thickness on a claw (categorized by quartiles within lactation number and within claw, the bounds for which are presented in Table 3) was associated with the highest odds of developing a lesion: claws with sole soft tissue thickness within the thinnest quartile were at greater odds of experiencing a lesion than those within the thickest quartile (odds ratio: 4.20, CI: 2.0-9.0). In alternative models, other descriptors of sole soft tissue thickness were also significant; for example, a continuous term of sole soft tissue thickness demonstrated the same result: that thinner sole soft tissues at the previous AP were associated with increased odds of lesion presence (model not shown). Additional models demonstrated that thin sole soft tissues predisposed both sole hemorrhage and sole ulcer, independently (not displayed).

Model $\mathbf{1 b}$. The outcome for model $1 \mathrm{~b}$ was the presence of either a sole ulcer or sole hemorrhage at a claw assessment, where 2 previous assessments of sole soft tissue thickness and back fat thickness were available (i.e., outcomes were measured at $\mathrm{AP}+9, \mathrm{AP}+17$, or $\mathrm{AP}+29)$. The model consisted of 1,616 claw assessments of 624 claws of 167 animals, and 100 cases of the outcome lesion were identified. The odds of a lesion being present at the current AP increased with thin-

Table 1. Incidence of claw horn disruption lesions during a longitudinal study of sole soft tissue thickness, and lesion and lameness incidence ${ }^{1}$

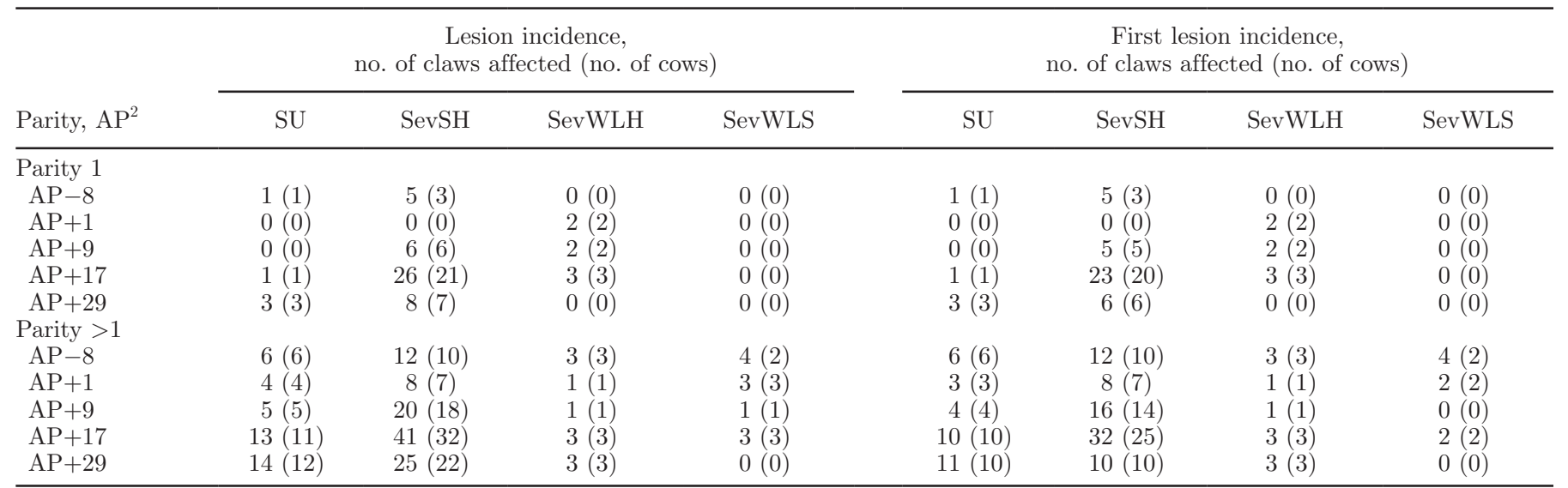

${ }^{1} \mathrm{SU}=$ sole ulcer; SevSH = severe sole hemorrhage; SevWLH = severe white line hemorrhage; SevWLS = severe white line separation.

${ }^{2}$ Weeks relative to calving. $\mathrm{AP}=$ assessment point. 
A)

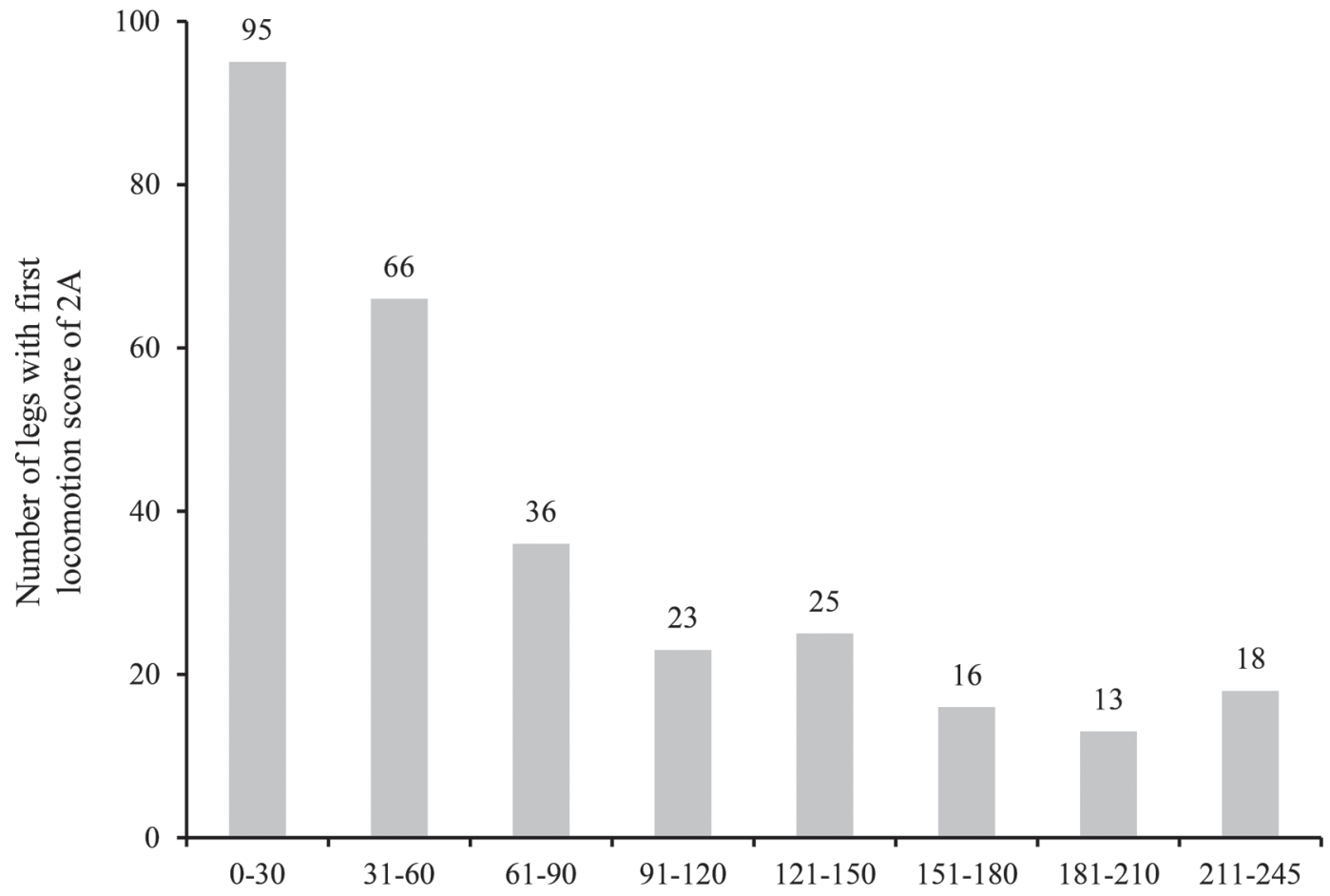

B)

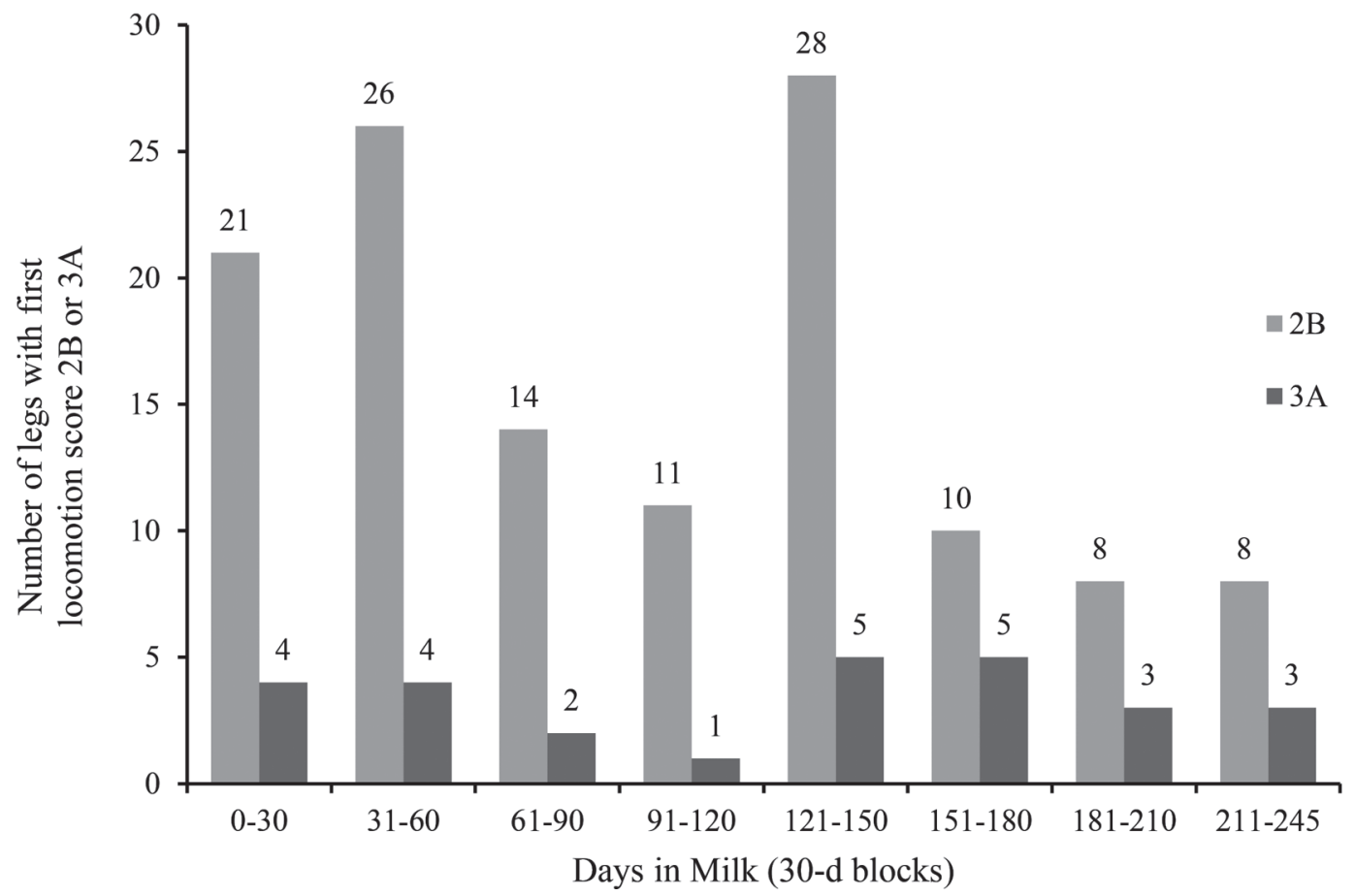

Figure 1. Incidence of first lameness after calving, in cows on a longitudinal study of sole soft tissue thickness and lameness. Data are at the leg level and are of hind leg locomotion scores only. Locomotion scores are grouped into 30-d periods throughout lactation. For each descriptor of locomotion score, a leg can only appear once. (A) First locomotion scores of 2A on each leg are shown. (B) First locomotion scores of 2B and of $3 \mathrm{~A}$ or greater on each leg are shown. 
THINNING OF THE DIGITAL CUSHION AND CORIUM

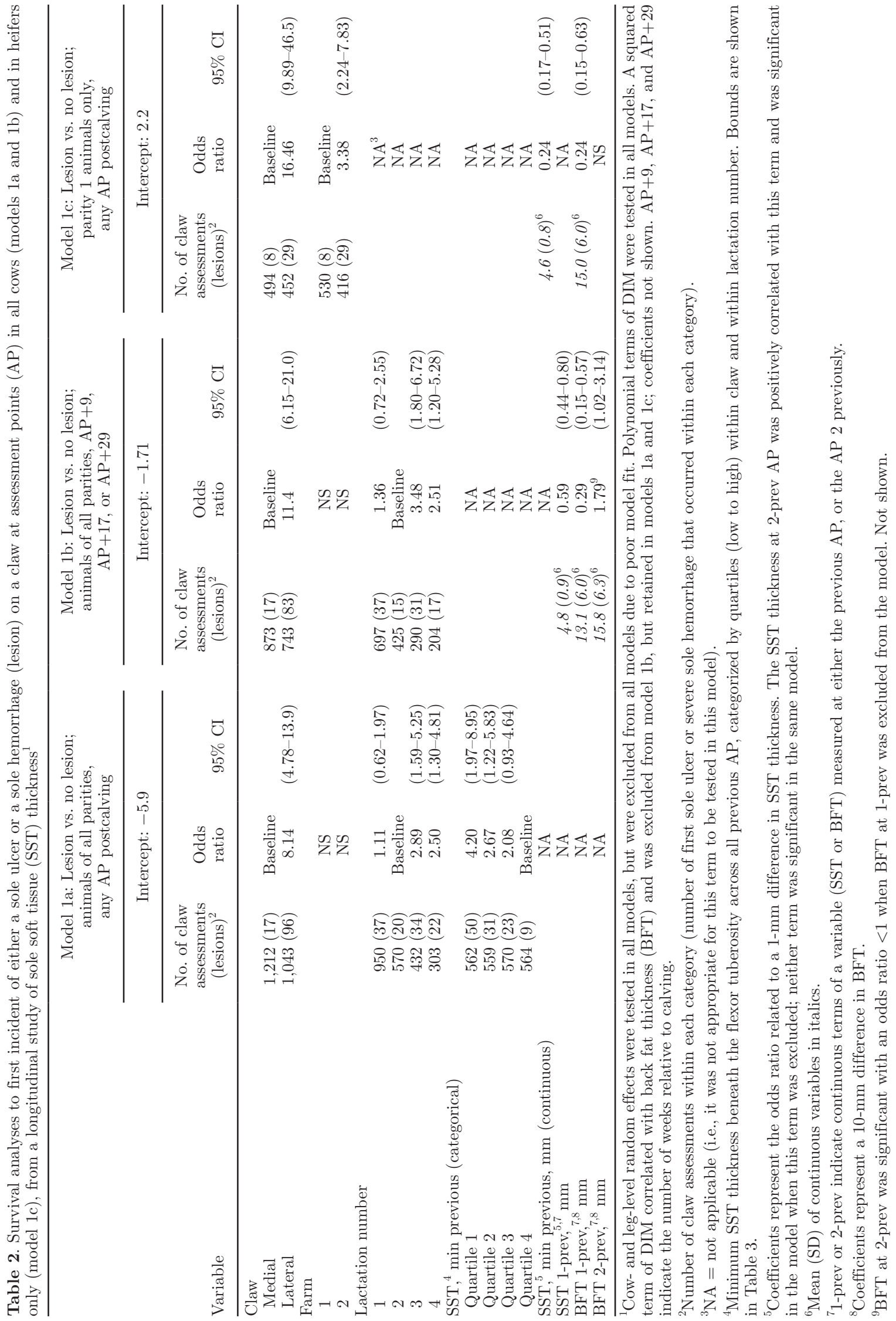


ner sole soft tissue thickness at the previous AP (odds ratio: 1.7 , CI: $1.3-2.7$ for a $1-\mathrm{mm}$ thinner sole soft tissue thickness); in a separate model, the odds of a lesion being present were also higher with thinner sole soft tissues at 2 AP previously, although the model is not shown. However, change in sole soft tissue thickness between AP did not influence the odds of a subsequent lesion incident in any models tested. Thin back fat at either of the 2 previous AP increased the odds of a lesion incident, yet when both terms of back fat thickness were included in the model, thicker back fat 2 AP previously increased the odds of a lesion incident (i.e., loss of back fat between AP also increased the odds of a lesion occurring).

Model 1c. Model 1c used data from parity 1 animals only, and modeled 946 claw assessments postcalving of 262 claws of 66 heifers; a lesion occurred on 37 claws. Odds of lesion occurrence were higher on the lateral claw, on farm 2 (odds ratio: $3.4,2.2-7.8$ ), with thinner back fat thickness at the previous AP and with thinner sole soft tissue thickness at the previous AP. Some variables in the model were correlated: both back fat thickness and sole soft tissue thickness were thinner on farm 2. Change in back fat thickness did not predict lameness events in first lactation animals.

\section{Survival Analyses of First Lameness Events, Measured by Locomotion Score (Models 2a and 2b)}

Overview of Final Lameness Models. The outcome for the lameness models was the first lame event (as measured by locomotion score) on a leg, which was defined as 2 locomotion scores of $>1$ within 3 consecutive locomotion scores every $2 \mathrm{wk}$ that included at least one $\geq 2 \mathrm{~A}$ and at least one $\geq 2 \mathrm{~B}$, versus a nonlame event. Including leg-locomotion scores up until first leg lameness, the data set consisted of 3,946 scores from 346 legs of 173 cows; 110 legs became lame between calving and 245 DIM. Two final models are presented (models $2 \mathrm{a}$ and $2 \mathrm{~b}$, Table 4 ), and both found that thin sole soft tissue thickness at site 3 on the lateral claw increased the odds of a leg becoming lame. Sole soft tissue thickness on the medial claw had no bearing on lameness incidents in any model.

Models were tested where the definition of the lameness as the outcome was different, for example when a lame event was defined as 2 consecutive locomotion scores $>1$. Similar associations between sole soft tissue thickness or back fat thickness and lameness were observed (i.e., thin sole soft tissue thickness increased the odds of lameness at future locomotion scores).

Model 2a. The outcome for model 2a was a lame or nonlame event at any locomotion score between calving and 245 DIM. The data set consisted of all 3,946 leglocomotion scores and a cow-level random effect was included. Model 2a demonstrated that if a leg had a sole soft tissue thickness on the lateral claw at $\mathrm{AP}-8$ of $1 \mathrm{~mm}$ thinner, it was at higher odds of becoming lame at each locomotion score (odds ratio: 1.4, 1.1-1.8). The likelihood of lameness also increased with lactation number. The random effect, which improved model fit, suggested that if a cow went lame on one hind leg, the other hind leg was at increased risk of lameness compared with the legs of cows that experienced lameness on neither hind leg.

Model 2b. The outcome for model 2b was a lame or nonlame event within 90 to $150 \mathrm{~d}$ following an AP. Model fit was poor when parity 1 animals were included; therefore, the model was based on data from parity $>1$ animals only, and the data set included 1,778 lameness assessments of 178 legs of 100 parity $>1$ animals; 55 legs experienced a first lameness event during that lactation within this period. Model $2 \mathrm{~b}$ is a fixed effects model as model fit deteriorated with the inclusion of

Table 3. Bounds for the quartiles of minimum previous sole soft tissue thickness [SST, min previous (categorical)] used in model 1a, by claw (lateral vs. medial) and lactation number

\begin{tabular}{|c|c|c|c|c|c|c|c|c|c|}
\hline \multirow{3}{*}{$\begin{array}{l}\mathrm{SST}^{1} \text { min previous } \\
\text { (categorical) }\end{array}$} & \multirow[b]{3}{*}{ Claw } & \multicolumn{8}{|c|}{ Bounds, mm } \\
\hline & & \multicolumn{2}{|c|}{ Lactation 1} & \multicolumn{2}{|c|}{ Lactation 2} & \multicolumn{2}{|c|}{ Lactation 3} & \multicolumn{2}{|c|}{ Lactation 4} \\
\hline & & Lower & Upper & Lower & Upper & Lower & Upper & Lower & Upper \\
\hline \multirow[t]{2}{*}{ Quartile 1} & Medial & 2.81 & 3.68 & 2.85 & 3.76 & 2.65 & 3.59 & 3.17 & 3.73 \\
\hline & Lateral & 3.22 & 4.45 & 2.72 & 4.66 & 3.45 & 4.75 & 3.26 & 4.59 \\
\hline \multirow[t]{2}{*}{ Quartile 2} & Medial & 3.68 & 4.07 & 3.77 & 4.08 & 3.61 & 4.17 & 3.76 & 4.15 \\
\hline & Lateral & 4.45 & 4.87 & 4.66 & 5.11 & 4.77 & 5.27 & 4.60 & 5.29 \\
\hline \multirow[t]{2}{*}{ Quartile 3} & Medial & 4.07 & 4.57 & 4.09 & 4.48 & 4.19 & 4.70 & 4.15 & 4.70 \\
\hline & Lateral & 4.88 & 5.44 & 5.15 & 5.56 & 5.28 & 5.98 & 5.30 & 5.87 \\
\hline \multirow[t]{2}{*}{ Quartile 4} & Medial & 4.58 & 6.53 & 4.50 & 5.95 & 4.71 & 7.12 & 4.74 & 7.04 \\
\hline & Lateral & 5.45 & 6.91 & 5.56 & 7.49 & 5.98 & 7.94 & 5.87 & 7.68 \\
\hline
\end{tabular}

${ }^{1}$ Quartiles displayed within claw and within lactation number. 
random effects. Cows in lactations 3 and 4 were more likely to go lame than those in lactation 2. Legs with sole soft tissue thickness on the lateral claw of $1 \mathrm{~mm}$ thinner during the period 90 to $150 \mathrm{~d}$ before a locomotion score were at increased the odds of being scored lame at that locomotion score (odds ratio: $1.7, \mathrm{CI}: 1.2$ to 2.3). Days in milk was retained in the model. Back fat thickness had no additional effect on the effect of sole soft tissue thickness. When the model was reconstructed to include assessments within the 30 to $90 \mathrm{~d}$ after calving, having a thinner sole soft tissue thickness during the 30 to $90 \mathrm{~d}$ before a locomotion score did not increase the odds of lameness.

\section{DISCUSSION}

These analyses found that a thin sole soft tissue thickness increased the likelihood of future lameness and CHDL incidents, yet a reduction in sole soft tissue thickness did not. One possible reason for thin sole soft tissues is a depletion of body fat, leading to thinning of the digital cushion (Bicalho et al., 2009). Model 1b found an additional effect of loss of back fat on lesion incidents to thinness of the sole soft tissues, suggesting that back fat thickness and sole soft tissue thickness had independent effects on lesion occurrence. To address the null hypothesis, change in thickness of the sole soft tissues did not increase either the risk of lesion or lameness occurrence.

Thin sole soft tissues increased the likelihood of either a sole ulcer or a sole hemorrhage occurring at future AP; the increased risk of sole hemorrhage with thin sole soft tissues has not previously been reported. The link appears plausible as sole hemorrhage and sole ulcer appear to be different stages of the same disease process, whereby insufficient impact absorption and insufficient force dissipation through the support structures of the foot result in inappropriately great forces being applied to the germinal epithelium that produces the sole horn, leading to vascular impairment and disruption of keratogenesis and ultimately manifesting as hemorrhage and ulceration (Nuss, 2014). The work adds to evidence that the 2 lesions are part of the same disease process, and therefore the 2 lesions may share similar control measures.

Thin sole soft tissue thickness increased the risk of both subsequent lameness events and lesion occurrence. Newsome et al. (2017) found that back fat thickness did

Table 4. Survival analyses to first lameness incident (defined as 1 locomotion score of $>2 \mathrm{~A}$ and 1 of $>2 \mathrm{~B}$ on a leg over 3 consecutive locomotion scores) at locomotion scores postcalving (model 2a) and using data collected within 90 to $150 \mathrm{~d}$ before a locomotion score in parity $>1$ animals (model 2b) during a longitudinal study of sole soft tissue (SST) thickness ${ }^{1,2}$

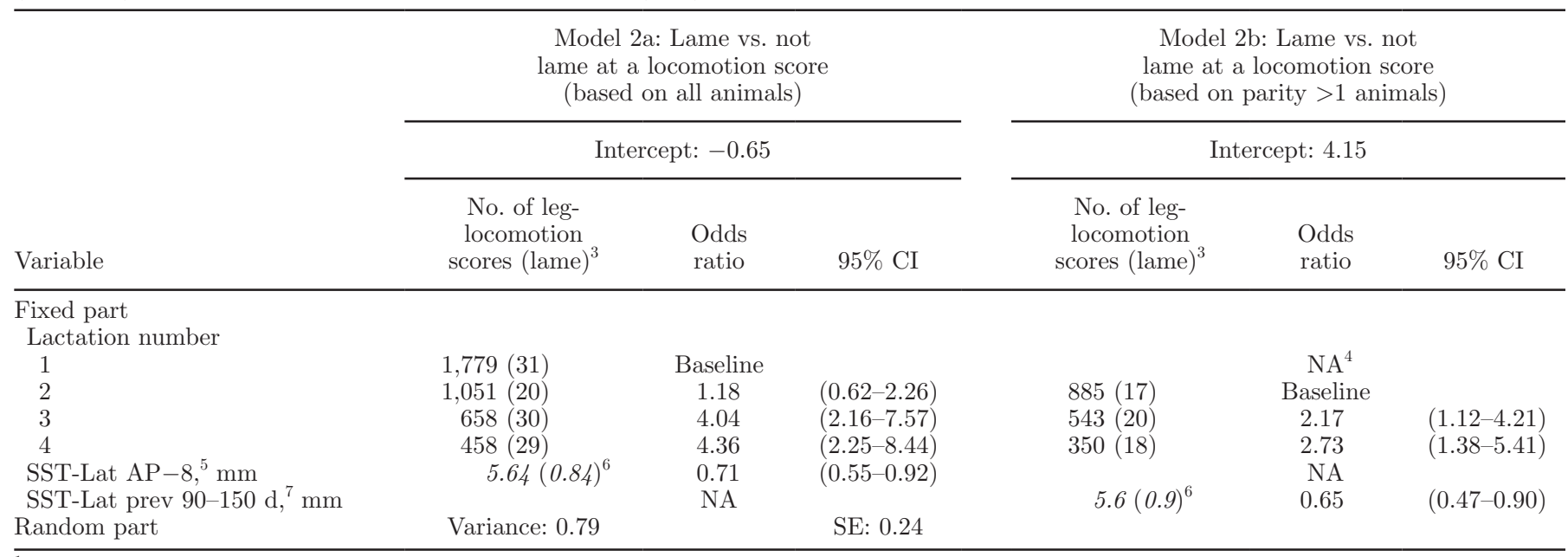

${ }^{1}$ Model 2a: data set included 3,946 leg-locomotion scores between calving and 35 wk in milk (or first lameness) of 346 legs of 173 cows of all parities. Model 2b: data set included 1,778 locomotion scores of 178 legs of 100 parity $>1$ animals, where locomotion scores were within 90 to 150 d after a SST measurement.

${ }^{2}$ Cow- and leg-level random effects were tested in all models. A cow-level random effect was retained in model $2 \mathrm{a}$, but excluded from model $2 \mathrm{~b}$ due to poor fit. Polynomial terms of DIM were tested to model time in all models, and retained in both models. Coefficients not shown.

${ }^{3}$ Number of leg-locomotion scores within each category for categorical variables (number of scores at which a leg was lame).

${ }^{4} \mathrm{NA}=$ not applicable; term not tested in this model.

${ }^{5} \mathrm{SST}$ thickness at site 3 (beneath the flexor tuberosity) on the lateral claw at AP-8.

${ }^{6}$ Mean (SD) of continuous variables indicated in italics.

${ }^{7}$ SST thickness at site 3 (beneath the flexor tuberosity) on the lateral claw during 90 to $150 \mathrm{~d}$ before the locomotion score. When locomotion scores were tested 30 to $90 \mathrm{~d}$ following a SST measurement, thin SST did not significantly increase the odds of lameness $(P=0.13)$. 
not explain much variation in sole soft tissue thickness throughout lactation in the same data set; therefore, it is reasonable to assume that the sole soft tissues were thin for reasons over and above that of mobilization of body fat alone. Other possible reasons for the sole soft tissues being thin could include (1) differences in digital cushion development in early life (Gard et al., 2015), (2) previous lameness, which could cause damage and changes to the digital cushion (Lischer et al., 2002), or (3) laxity in the suspensory apparatus. The third possibility encapsulates a poorly understood area of bovine anatomy and physiology and is explored further below.

Factors influencing the suspensory apparatus of the distal phalanx in the development of CHDL have been considered for decades (e.g., Greenough et al., 1981; Vermunt and Greenough, 1994). Evidence suggests that the integrity of the suspensory apparatus is implicated in the aetiopathogenesis of CHDL; for example, parturition has a profound effect (Tarlton et al., 2002; Knott et al., 2007), likely causing the distal phalanx to sit lower within the hoof capsule (Newsome et al., 2017). This could explain why lesion incidence peaks within the first few months of lactation, following the initial insult to the germinal epithelium. Historically, subacute ruminal acidosis has also been thought to weaken the suspensory apparatus through laminitis, yet this theory has been disregarded by many researchers as the primary cause of most CHDL (Mulling and Greenough, 2006; Vermunt, 2007; Bicalho and Oikonomou, 2013). In equine lameness, recent advances in laminitis research have identified multiple pathogenic mechanisms behind the disease process (Katz and Bailey, 2012), and in one mechanism hyperinsulinemia affects the integrity of the suspensory apparatus in vivo, causing noninflammatory changes in and distension of laminar morphology; the term laminitis is even being replaced with laminopathy to reflect noninflammatory changes within the laminae early in the disease process. This occurs in the absence of gastrointestinal involvement, systemic illness, or inflammatory infiltration into laminae (Asplin et al., 2007), and carbohydrate overload appears not to be implicated in all equine laminitis mechanisms (de Laat et al., 2010, 2012; Selim et al., 2015). In cattle, disruption to laminar morphology has been described following oligofructose overload in the absence of inflammatory infiltration (Thoefner et al., 2005; Danscher et al., 2010), which could indicate that a noninflammatory pathologic process is occurring. Findings of Newsome et al. (2017) suggest that laxity of the suspensory apparatus might be a function of physiologic state and it remains possible that insulin could be implicated in laminar alterations in cattle, too. Laminar pathology caused by mechanisms that have not yet been identified might underlie CHDL in cattle and this could be a pertinent area for future research.

Previous epidemiological research has found that both being thin and loss of body condition are risk factors for lameness and CHDL incidence (Green et al., 2014; Lim et al., 2015; Randall et al., 2015). One proposed explanation is that mobilization of adipose from the digital cushion decreases its force-dissipating capacity and leads to contusions within the germinal epithelium of the sole (Bicalho et al., 2009). The current study found that although thin sole soft tissues increased the risk of lameness and lesion occurrence, and although loss of back fat increased the risk of lesions, thinning of the sole soft tissues barely occurred with loss of back fat (Newsome et al., 2017) and thinning of the sole soft tissues did not increase the risk of lameness or lesions. This illustrates that an effect of body condition loss on lameness through the mechanism of thinning of the digital cushion was, if present, too small to be detected in the current study.

A key hypothesis that remains unaddressed is whether manipulation of body condition loss can reduce lameness incidence. High-producing cows undergo body condition loss in early lactation (Waltner et al., 1993). This is partly an effect of genotype, whereby body fats are mobilized to provide feed for the neonate through a homeorhetic process (in part, mediated by insulin resistance). Higher producing cows have higher levels of insulin resistance (Chagas et al., 2009) and consequently mobilize greater amounts of body fat and lose more condition (Smith and McNamara, 1990; Roche et al., 2006; Kay et al., 2009). Claw horn disruption lesion is known to be a disease of higher producing cows (Amory et al., 2008; Bicalho et al., 2008), and as such, the link between body condition loss and CHDL may not be causal, but both could be predisposed by another common factor, such as genotype. Even small losses in body condition can increase the risk of lameness (Lim et al., 2015; Randall et al., 2015) and these losses could be part of the homeorhetic process that is not affected by caloric intake, which may be unpreventable (Roche et al., 2009). However, genetic selection to improve energy reserve management is possible and has wide-reaching benefits for health and productivity of the dairy cow (Banos and Coffey, 2010; Bastin et al., 2012). Further work should assess whether minimizing body condition loss during early lactation reduces lameness incidence and serves as a realistic control point for lameness.

Previous work found that having thin sole soft tissues increased the likelihood of sole ulcer and white line disease, when the lesions were used as a combined outcome, where 114 cases of sole ulcer and 26 cases of white line disease were recorded (Machado et al., 2011). 
The current work did not detect an increased risk of white line lesions with thin sole soft tissues, although a very low incidence of white line lesions occurred and our work may have lacked power to detect differences with sole soft tissue thickness. Furthermore, sole soft tissue thickness was not measured in the region of the white line. It remains possible that the digital cushion and other force-dissipating structures of the foot play a role in the pathogenesis of white line lesions (Machado et al., 2011; Newsome et al., 2017).

In previous works and in the current study, thin sole soft tissue thickness increased the risk of lameness. The sole soft tissues could have been thin as a result of trauma during previous CHDL that might have caused thinning (Lischer et al., 2002), rather than the sole soft tissues being thin for a physiological reason. However, it is not clear whether the thin digital cushion around calving that influenced future lameness was a result of prior lameness [Newsome et al. (2017) found at least an effect of calving on sole soft tissue thickness], and despite possible effects of prior lesion occurrence on sole soft tissue thickness, important results were still observed in this work. Additionally, thin sole soft tissues increased the likelihood of lesion occurrence in heifers too; it could be assumed that lesions in heifers were first significant lifetime lesions; therefore, these animals could have had little or no disruption to digital cushion architecture before first lameness. Another hypothesis that further work could explore is whether acute failure of the suspensory apparatus, for whatever reason, causes thinning of the sole soft tissues and CHDL.

\section{CONCLUSIONS}

In this study, thin sole soft tissue thickness predisposed lameness and lesions later in lactation, whereas thinning of sole soft tissue thickness did not influence the likelihood of future lameness or lesion occurrence. Many variables could have contributed toward a thin digital cushion, including measures of back fat, factors that influence the suspensory apparatus of the hoof such as calving or laminar pathology, or prior lameness. In addition to many extrinsic risk factors, lameness appears to be predisposed by intrinsic factors too, including poorly understood physiological mechanisms, which could incorporate insulin resistance and body condition loss, and remains an area where much knowledge is to be gained.

\section{ACKNOWLEDGMENTS}

This work constituted part of a doctoral thesis by the first author, which contains further validation and analysis. A digital version of the thesis will be available from http://eprints.nottingham.ac.uk late in 2017. The work was funded by the Agriculture and Horticulture Development Board Dairy Division (Kenilworth, UK), a levy board, not-for-profit organization working on behalf of British dairy farmers. The authors thank Katie Holmes (School of Veterinary Medicine and Science, University of Nottingham, UK) for technical support throughout the project and farm staff for accommodating the study.

\section{REFERENCES}

Amory, J. R., Z. E. Barker, J. L. Wright, S. A. Mason, R. W. Blowey, and L. E. Green. 2008. Associations between sole ulcer, white line disease and digital dermatitis and the milk yield of 1824 dairy cows on 30 dairy cow farms in England and Wales from February 2003-November 2004. Prev. Vet. Med. 83:381-391. https://doi. org/10.1016/j.prevetmed.2007.09.007.

Asplin, K. E., M. N. Sillence, C. C. Pollitt, and C. M. McGowan. 2007. Induction of laminitis by prolonged hyperinsulinaemia in clinically normal ponies. Vet. J. 174:530-535. https://doi.org/10.1016/j. tvjl.2007.07.003.

Banos, G., and M. P. Coffey. 2010. Genetic association between body energy measured throughout lactation and fertility in dairy cattle. Animal 4:189-199.

Barker, Z. E., J. R. Amory, J. L. Wright, R. W. Blowey, and L. E. Green. 2007. Management factors associated with impaired locomotion in dairy cows in England and Wales. J. Dairy Sci. 90:32703277. https://doi.org/10.3168/jds.2006-176.

Bastin, C., D. P. Berry, H. Soyeurt, and N. Gengler. 2012. Genetic correlations of days open with production traits and contents in milk of major fatty acids predicted by mid-infrared spectrometry. J. Dairy Sci. 95:6113-6121. https://doi.org/10.3168/jds.2012-5361.

Berry, S. L., D. H. Read, T. R. Famula, A. Mongini, and D. Döpfer. 2012. Long-term observations on the dynamics of bovine digital dermatitis lesions on a California dairy after topical treatment with lincomycin HCl. Vet. J. 193:654-658. https://doi.org/10.1016/j. tvjl.2012.06.048.

Bicalho, R. C., V. S. Machado, and L. S. Caixeta. 2009. Lameness in dairy cattle: A debilitating disease or a disease of debilitated cattle? A cross-sectional study of lameness prevalence and thickness of the digital cushion. J. Dairy Sci. 92:3175-3184. https://doi. org/10.3168/jds.2008-1827.

Bicalho, R. C., and G. Oikonomou. 2013. Control and prevention of lameness associated with claw lesions in dairy cows. Livest. Sci. 156:96-105. https://doi.org/10.1016/j.livsci.2013.06.007.

Bicalho, R. C., L. D. Warnick, and C. L. Guard. 2008. Strategies to analyze milk losses caused by diseases with potential incidence throughout the lactation: A lameness example. J. Dairy Sci. 91:2653-2661. https://doi.org/10.3168/jds.2007-0744.

Cha, E., J. A. Hertl, D. Bar, and Y. T. Grohn. 2010. The cost of different types of lameness in dairy cows calculated by dynamic programming. Prev. Vet. Med. 97:1-8. https://doi.org/10.1016/j. prevetmed.2010.07.011.

Chagas, L. M., M. C. Lucy, P. J. Back, D. Blache, J. M. Lee, P. J. S. Gore, A. J. Sheahan, and J. R. Roche. 2009. Insulin resistance in divergent strains of Holstein-Friesian dairy cows offered fresh pasture and increasing amounts of concentrate in early lactation. J. Dairy Sci. 92:216-222. https://doi.org/10.3168/jds.2008-1329.

Cox, D. R., and D. Oakes. 1984. Analysis of Survival Data. Chapman and Hall, London, UK.

Danscher, A. M., T. H. Toelboell, and O. Wattle. 2010. Biomechanics and histology of bovine claw suspensory tissue in early acute laminitis. J. Dairy Sci. 93:53-62. https://doi.org/10.3168/jds.20092038 . 
de Laat, M. A., C. M. McGowan, M. N. Sillence, and C. C. Pollitt. 2010. Equine laminitis: Induced by $48 \mathrm{~h}$ hyperinsulinaemia in Standardbred horses. Equine Vet. J. 42:129-135. https://doi. org $/ 10.2746 / 042516409 X 475779$.

de Laat, M. A., M. N. Sillence, C. M. McGowan, and C. C. Pollitt. 2012. Continuous intravenous infusion of glucose induces endogenous hyperinsulinaemia and lamellar histopathology in Standardbred horses. Vet. J. 191:317-322. https://doi.org/10.1016/j. tvj1.2011.07.007.

Döpfer, D., A. Koopmans, F. A. Meijer, I. Szakall, Y. H. Schukken, W. Klee, R. B. Bosma, J. L. Cornelisse, A. vanAsten, and A. terHuurne. 1997. Histological and bacteriological evaluation of digital dermatitis in cattle, with special reference to Spirochaetes and Campylobacter faecalis. Vet. Rec. 140:620-623.

Edmonson, A. J., I. J. Lean, L. D. Weaver, T. Farver, and G. Webster. 1989. A body condition scoring chart for Holstein dairy cows. J. Dairy Sci. 72:68-78.

Foditsch, C., G. Oikonomou, V. S. Machado, M. L. Bicalho, E. K. Ganda, S. F. Lima, R. Rossi, B. L. Ribeiro, A. Kussler, and R. C. Bicalho. 2016. Lameness prevalence and risk factors in large dairy farms in Upstate New York. Model development for the prediction of claw horn disruption lesions. PLoS One 11:e0146718 https:// doi.org/10.1371/journal.pone.0146718.

Gard, J. A., D. R. Taylor, D. R. Wilhite, S. P. Rodning, M. L. Schnuelle, R. K. Sanders, R. J. Beyers, M. A. Edmondson, F. J. DeGraves, and E. van Santen. 2015. Effect of exercise and environmental terrain on development of the digital cushion and bony structures of the bovine foot. Am. J. Vet. Res. 76:246-252. https:// doi.org/10.2460/ajvr.76.3.246.

Goldstein, H. 2003. Multilevel Statistical Models. Hodder Arnold, London, UK.

Green, L. E., J. N. Huxley, C. Banks, and M. J. Green. 2014. Temporal associations between low body condition, lameness and milk yield in a UK dairy herd. Prev. Vet. Med. 113:63-71. https://doi. org/10.1016/j.prevetmed.2013.10.009.

Greenough, P. R., F. J. MacCallum, and A. D. Weaver. 1981. Lameness in Cattle. Wright-Scientechnica, Bristol, UK.

Greenough, P. R., and J. J. Vermunt. 1991. Evaluation of subclinical laminitis in a dairy herd and observations on associated nutritional and management factors. Vet. Rec. 128:11-17.

Hosmer, D. W., and S. Lemeshow. 1989. Applied Logistic Regression. Wiley, New York, NY.

Katz, L. M., and S. R. Bailey. 2012. A review of recent advances and current hypotheses on the pathogenesis of acute laminitis. Equine Vet. J. 44:752-761. https://doi.org/10.1111/j.20423306.2012.00664.x.

Kay, J. K., C. V. Phyn, J. R. Roche, and E. S. Kolver. 2009. Extending lactation in pasture-based dairy cows. II: Effect of genetic strain and diet on plasma hormone and metabolite concentrations. J. Dairy Sci. 92:3704-3713. https://doi.org/10.3168/jds.2008-1976.

Knott, L., J. F. Tarlton, H. Craft, and A. J. F. Webster. 2007. Effects of housing, parturition and diet change on the biochemistry and biomechanics of the support structures of the hoof of dairy heifers. Vet. J. 174:277-287. https://doi.org/10.1016/j.tvjl.2006.09.007.

Leach, K. A., D. N. Logue, S. A. Kempson, J. E. Offer, H. E. Ternent, and J. M. Randall. 1997. Claw lesions in dairy cattle: Development of sole and white line haemorrhages during the first lactation. Vet. J. 154:215-225.

Lim, P. Y., J. N. Huxley, J. A. Willshire, M. J. Green, A. R. Othman, and J. Kaler. 2015. Unravelling the temporal association between lameness and body condition score in dairy cattle using a multistate modelling approach. Prev. Vet. Med. 118:370-377. https:// doi.org/10.1016/j.prevetmed.2014.12.015.

Lischer, C. J., P. Ossent, M. Räber, and H. Geyer. 2002. Suspensory structures and supporting tissues of the third phalanx of cows and their relevance to the development of typical sole ulcers (Rusterholz ulcers). Vet. Rec. 151:694-698.

Machado, V. S., L. S. Caixeta, and R. C. Bicalho. 2011. Use of data collected at cessation of lactation to predict incidence of sole ulcers and white line disease during the subsequent lactation in dairy cows. Am. J. Vet. Res. 72:1338-1343. https://doi.org/10.2460/ ajvr.72.10.1338.

Mulling, C., and P. R. Greenough. 2006. Applied Physiopathology of the Foot. XXIV World Buiatrics Congress. Nice, France. World Association for Buiatrics, Paris, France.

Newsome, R. F., M. J. Green, N. J. Bell, C. S. Mason, H. R. Whay, and J. N. Huxley. 2017. A prospective cohort study of the digital cushion and corium. Part 1: Associations with body condition, lesion incidence and proximity to calving. J. Dairy Sci. 100:47454758. https://doi.org/10.3168/jds.2016-12012.

Nuss, K. 2014. The role of biomechanical factors in the development of sole ulcer in dairy cattle. Pages 1-11 in Cattle Lameness Conference, Worcester. The Dairy Group, Taunton, UK.

Räber, M., C. J. Lischer, H. Geyer, and P. Ossent. 2004. The bovine digital cushion-A descriptive anatomical study. Vet. J. 167:258264.

Räber, M., M. R. L. Scheeder, P. Ossent, C. J. Lischer, and H. Geyer. 2006. The content and composition of lipids in the digital cushion of the bovine claw with respect to age and location-A preliminary report. Vet. J. 172:173-177.

Randall, L. V., M. J. Green, M. G. G. Chagunda, C. Mason, S. C. Archer, L. E. Green, and J. N. Huxley. 2015. Low body condition predisposes cattle to lameness: An 8-year study of one dairy herd. J. Dairy Sci. 98:3766-3777. https://doi.org/10.3168/jds.2014-8863.

Rasbash, J., F. Steele, W. J. Browne, and H. Goldstein. 2009. A User' Guide to MLwiN. Centre for Multilevel Modelling, University of Bristol, Bristol, UK.

Roche, J. R., D. P. Berry, and E. S. Kolver. 2006. Holstein-Friesian strain and feed effects on milk production, body weight, and body condition score profiles in grazing dairy cows. J. Dairy Sci. 89:3532-3543. https://doi.org/10.3168/jds.S0022-0302(06)723931.

Roche, J. R., N. C. Friggens, J. K. Kay, M. W. Fisher, K. J. Stafford, and D. P. Berry. 2009. Invited review: Body condition score and its association with dairy cow productivity, health, and welfare. J. Dairy Sci. 92:5769-5801. https://doi.org/10.3168/jds.2009-2431.

Schindelin, J., I. Arganda-Carreras, E. Frise, V. Kaynig, M. Longair, T. Pietzsch, S. Preibisch, C. Rueden, S. Saalfeld, B. Schmid, J.-Y. Tinevez, D. J. White, V. Hartenstein, K. Eliceiri, P. Tomancak, and A. Cardona. 2012. Fiji: an open-source platform for biologicalimage analysis. Nat. Methods 9:676-682. https://doi.org/10.1038/ nmeth.2019.

Schneider, C. A., W. S. Rasband, and K. W. Eliceiri. 2012. NIH Image to ImageJ: 25 years of image analysis. Nat. Methods 9:671-675.

Selim, S. K. Elo, S. Jaakkola, N. Karikoski, R. Boston, T. Reilas, S. Särkijärvi, M. Saastamoinen, and T. Kokkonen. 2015. Relationships among body condition, insulin resistance and subcutaneous adipose tissue gene expression during the grazing season in mares. PLoS One 10:e0125968. https://doi.org/10.1371/journal. pone.0125968.

Smith, T. R., and J. P. McNamara. 1990. Regulation of bovine adipose tissue metabolism during lactation. 6. Cellularity and hormonesensitive lipase activity as affected by genetic merit and energy intake. J. Dairy Sci. 73:772-783.

Sogstad, A. M., O. Osteras, T. Fjeldaas, and A. O. Refsdal. 2007. Bovine claw and limb disorders at claw trimming related to milk yield. J. Dairy Sci. 90:749-759.

Tarlton, J. F., D. E. Holah, K. M. Evans, S. Jones, G. R. Pearson and A. J. F. Webster. 2002. Biomechanical and histopathological changes in the support structures of bovine hooves around the time of first calving. Vet. J. 163:196-204. https://doi.org/10.1053/ tvjl.2001.0651.

Thoefner, M. B., O. Wattle, C. C. Pollitt, K. R. French, and S. S. Nielsen. 2005. Histopathology of oligofructose-induced acute laminitis in heifers. J. Dairy Sci. 88:2774-2782.

Thomas, H. J., G. G. Miguel-Pacheco, N. J. Bollard, S. C. Archer, N J. Bell, C. Mason, O. J. R. Maxwell, J. G. Remnant, P. Sleeman, H. R. Whay, and J. N. Huxley. 2015. Evaluation of treatments for claw horn lesions in dairy cows in a randomized controlled trial. J. Dairy Sci. 98:4477-4486. https://doi.org/10.3168/jds.2014-8982. 
Thomas, H. J., J. G. Remnant, N. J. Bollard, H. R. Whay, N. J. Bell, C. Mason, and J. N. Huxley. 2016. Recovery of chronically lame dairy cows following treatment for claw horn lesions: A randomised controlled trial. Vet. Rec. 178:116.

Toholj, B., M. Cincović, M. Stevančević, J. Spasojevic, V. Ivetić, and A. Potkonjak. 2014. Evaluation of ultrasonography for measuring solar soft tissue thickness as a predictor of sole ulcer formation in Holstein-Friesian dairy cows. Vet. J. https://doi.org/10.1016/j. tvjl.2013.11.005.

van Amstel, S. R., and J. K. Shearer. 2006. Review of Pododermatitis circumscripta (ulceration of the sole) in dairy cows. J. Vet. Intern. Med. 20:805-811. https://doi.org/10.1111/j.1939-1676.2006. tb01789.x.

Vermunt, J. J. 2007. One step closer to unravelling the pathophysiology of claw horn disruption: For the sake of the cows' welfare. Vet. J. 174:219-220. https://doi.org/10.1016/j.tvjl.2006.10.006.
Vermunt, J. J., and P. R. Greenough. 1994. Predisposing factors of laminitis in cattle. Br. Vet. J. 150:151-164. https://doi.org/10.1016/ S0007-1935(05)80223-4.

Waltner, S. S., J. P. Mcnamara, and J. K. Hillers. 1993. Relationships of body condition score to production variables in high producing Holstein dairy cattle. J. Dairy Sci. 76:3410-3419. https://doi. org/10.3168/jds.S0022-0302(93)77679-1.

Wildman, E. E., G. M. Jones, P. E. Wagner, R. L. Boman, H. F. Troutt, and T. N. Lesch. 1982. A dairy-cow body condition scoring system and its relationship to selected production characteristics. J. Dairy Sci. 65:495-501.

Yang, M., and H. Goldstein. 2003. Modelling Survival data in MLwiN 1.20. Centre for Multilevel Modelling. University of London, London, UK. 